\title{
Impact of Customer Relationship Management of Hotel (A Case study Umaid Bhwan)
}

\author{
Dr. Tauseef Ahmad \\ Jai Narain Vays University \\ Department of accounting \\ Dr. Omar A.A. Jawabreh \\ Department of Tourism and Hotels Sciences \\ Al, Balqa Applied University, Jordan, Aqaba \\ E-mail: ojawabreh2000@yahoo.com \\ Mahmoud (abdel muhsen)Irsheid Al Afeef \\ Research scholar \\ Jai Narain Vays University
}

\author{
Alaa Almomani \\ Research scholar \\ University of Western Sydney
}

Received: February 5, 2012 Accepted: February 26, 2012 Published: June 1, 2012

doi:10.5296/ajfa.v4i1.1362ＵRL: http://dx.doi.org/10.5296/ajfa.v4i1.1362

\begin{abstract}
This paper is an attempt to find the variables factors that Influence customer relationship management of hotels (A Case study Umaid Bhwan) in India.

In this research, the Statistical Package for the Social Sciences (SPSS) was used for data entry, as well as for examining the data later. Data preparation was the initial step, which aimed to convert raw data into a more structured format that is more appropriate for analysis.
\end{abstract}




\section{Macrothink}

Asian Journal of Finance \& Accounting ISSN 1946-052X 2012, Vol. 4, No. 1

After analysis of the available data, it has been found there is impact of implementing customer relationship management to increase the customer trust in Umaid Bahwan with a medium degree where Umaid Bhwan employees have good skills, and customers feel confident with dealing with Umaid Bhwan hotel. The information customers get from the hotel is accurate. The hotel always exerts good efforts to fulfill its promises, so the customers could get the hotels services as promised.

Keywords: Umaid Bhwan hotel, Customer Relationship management, Hotel, Customized services, Customer loyalty. 


\section{Introduction}

Today, many businesses such as hotels, insurance companies, and other service providers realize the importance of Customer Relationship Management (CRM) and its potential to help them acquire new customers retain existing ones and maximize their lifetime value. At this point, close relationship with customers will require a strong coordination between IT and management departments to provide a long-term retention of selected customers. This paper deals with the role of Customer Relationship Management in Indian hotel sector and the need for Customer Relationship Management to increase customer value by using some analytical methods in CRM applications (Light, 2003).

CRM is a sound business strategy to identify the Umaid Bhwan most profitable customers and prospects, devotes time and attention to expanding account relationships with those customers through individualized management, reprising, discretionary decision making, and customized service-all delivered through the various sales channels that the hotel uses.

Customer Relationship Management (CRM) is one of those magnificent concepts that swept the business world in the 1990's with the promise of forever changing the way businesses small and large interacted with their customer bases. In the short term, however, it proved to be an unwieldy process that was better in theory than in practice for a variety of reasons. First among these was that it was simply so difficult and expensive to track and keep the high volume of records needed accurately and constantly update them.

\section{Literature of Review}

According to Light (2003), Customer Relationship Management is a process of managing customer relations in an organized way. They aim at managing each "Moment Of Truth" that is experienced by the customer. There are various contact points where the hotel comes in direct contact with the customer which are known as 'Touch points' in the CRM language. These touch points are considered important as there is direct interaction with the customer and they provide valuable input to the hotel. The input provided by the customer has to be captured in such a way that it becomes information and can be used by various processes within the hotel. it is based on the argument that "the happier a customer is with a relationship, the greater the likelihood they will stay with an organization". Moreover, the comprehension of the potential life-time value of a loyal customer to the company is also closely connected to its development.

(Chen and Popvich, 2003,). It is argued by some researchers that CRM can be seen as the organizational implementation of a relationship management philosophy (Ryals and Knox, 2001, Ryals and Payne, 2001). Through delivering more responsive and customized services to customers, CRM increases customer satisfaction and this, in turn, improves customer loyalty.

(Croteau and $\mathrm{Li}$, 2003).The importance of relationship management is increasingly being recognized. Kotler (1992) wrote that companies must move from short-term transaction-oriented goals to long-term relationship-building goals. (Jackson, 1994). The evolution of relationship management is also closely associated with the realization of the importance of the customer to a company the advancement of technology, the diminishing of product differences and the ever-increasing pressure of competition has led to the acknowledgement that customers are one of a company's most valuable assets. (Chen and 


\section{$\Lambda$ Macrothink}

Popvich, 2003,). It is argued by some researchers that CRM can be seen as the organizational implementation of a relationship management philosophy (Ryals and Knox, 2001, Ryals and Payne, 2001). Through delivering more responsive and customized services to customers, CRM increases customer satisfaction and this, in turn, improves customer loyalty. Ndubisi (2003) argued that the only real sustainable business growth strategy is through autoplastic symbiotic relationship with customers, which enables a business to understand their needs more clearly and to create and deliver superior value. Keltner (1995) found that German hotels, in contrast to American hotels, managed to maintain a stable market position during the 1980s and early 1990s because of relationship oriented hotel strategies.

(Johnson, 1999). The term also refers to a customer's perceptions of how well the whole relationship fulfils expectations, predictions, goals and desires the customer has concerning the whole relationship. Henning-Thurau et al., 2002). Customer Service is now more fashionably called Customer Relationship Management. The concept of Customer Relationship Management has a broader focus of not only serving the customer but also creating the customer and retaining him for measurable and substantial returns. Also, a review of literature has revealed that studies focusing on relationship management, service and satisfaction already exist. (Colgate et al., 2005; Martı́n-Consuegra et al., 2006).. CRM is a vast subject where Database Marketing supports the concept of one to one marketing. It is also remarkable that there is no research on the relationship between relational benefits and customer satisfaction in retail hotel. (O’Malley and Tynan, 2000). However, all customers do not want to engage in relationships and, in fact, it has been suggested that close customer relationships in hotel are rare, and that they are being further weakened by the increase in self-service technologies.

\section{Research Objectives}

The research aims to investigate the impact of customer relationship management on customer's satisfaction, trust, retention in UMAID BHWAN in India, in addition to the following:-

1. To find the impact of implementing customer relationships management to increase the customers trust to Umaid Bahwan.

2. To identify if there is an impact of implementing customer relationship management on customer satisfaction in Umaid Bahwan.

3. To find out if UMAID BHWAN implement customer relationship management in its management activities.

4. To find the relation between implementing Customer Relationship Management and customer retention in Umaid Bahwan.

5. To identify the differences of impact of customer relationship management on customers due to their demographic information

\section{Research Methodology}

\subsection{Data collection}

In this research, two types of data have been used; primary and secondary data.

Primary data have been collected through the answers received from side the customers of 
Umaid Bhwan in Jodhpur.

Secondary data that have been used in this research are from annual reports and accounts of State Hotel of India, Books, Journals, Periodicals and computer database.

All customers' department officials in state hotel of India (Umaid Bahwan) have been deemed as research population.

\subsection{Hypotheses}

H0: There is no impact of implementing customer relationship management to increase the customer trust in Umaid Bahwan.

H0: There is no impact of implementing customer relationship management on customer satisfaction in Umaid Bahwan.

H0: UMAID BHWAN hotel does not implement customer relationship management in its Management activities.

H0: There are no relations between Customer Relationship Management and customer retention in Umaid Bahwan.

H0: There are no differences in impact of customer relationship management on customers due to their demographic information.

\subsection{Data analyses}

In this research, the Statistical Package for the Social Sciences (SPSS) was used for data entry as well as for examining the data later. Data preparation was the initial step, which aimed to convert raw data into a more structured format that is more appropriate for analysis. Tasks in this stage included data editing, data coding and data entry. Descriptive statistics were used to summarize respondent's characteristics, including demographic information, such as age, gender; also questions about the participating company's profile, such as the numbers of Customer were included. Furthermore, inferential statistics were used to test hypotheses to determine the relationship between variables. In particular, Pearson Correlation was used to verify the association of interval level to the construct, whilst Chi-square was used to validate the association between nominal variables and the construct. Moreover, the Cronbach coefficient alpha was used for reliability tests. Lastly, the variable analysis tool, analysis of variance (ANOVA), was used to determine the impact of customer relationship management in State Hotel of India on the level of customer's trust, retention, satisfaction, and management activities.

4.4 Description of personal factors:

Table No. (1) Shows a description of personal and functional factors of the sample individuals, as follows:

- Gender : it is shown that $50.7 \%$ of the sample is male, and $49.3 \%$ is female

- Age range : it is shown that $43.3 \%$ of the sample their age from 21 to 30 years and $31.3 \%$ between 31-40 years, $12.7 \%$ between 51 to $60,6.7 \%$ of those less than 20 years, and $6.0 \%$ between 41 to 50 . 
- Monthly income: the table shows that $38.0 \%$ of the sample their income less than $1000 \$$, $24.7 \%$ between $1001 \$$ - 2000\$, $19.3 \%$ between $2001 \$$ - 3000\$, and $18.0 \%$ their income More than $3000 \$$.

- Occupation: $62.0 \%$ of the sample individuals is working in Private Sector, and 38.0 in Public Sector.

- Education: $36.7 \%$ of the sample study has Post Graduate degree, and 32.0\% of the sample has Bachelors degree, 12.7 \% of the sample has master's degree, and $18.7 \%$ has High School.

Table 1. the frequencies and percentages of the personal levels of the respondents

\begin{tabular}{|l|l|c|c|}
\hline Factor & & Frequency & percentage \\
\hline \multirow{4}{*}{ Gender } & Male & 76 & 50.7 \\
\cline { 2 - 4 } & Female & 74 & 49.3 \\
\hline \multirow{5}{*}{ Income } & less than 20 years & 10 & 6.7 \\
\cline { 2 - 4 } & $21-30$ years & 65 & 43.3 \\
\cline { 2 - 4 } & $31-40$ years & 47 & 31.3 \\
\cline { 2 - 4 } & $41-50$ years & 9 & 6.0 \\
\cline { 2 - 4 } & $51-60$ years & 19 & 12.7 \\
\hline \multirow{5}{*}{ Occupation } & less than $1000 \$$ & 57 & 38.0 \\
\cline { 2 - 4 } & $1001 \$-2000 \$$ & 37 & 24.7 \\
\cline { 2 - 4 } & $2001 \$-3000 \$$ & 29 & 19.3 \\
\cline { 2 - 4 } & More than 3000\$ & 27 & 18.0 \\
\hline \multirow{5}{*}{ Education } & Private Sector & 93 & 62.0 \\
\cline { 2 - 4 } & Public Sector & 57 & 38.0 \\
\cline { 2 - 4 } & High School & 19 & 12.7 \\
\cline { 2 - 4 } & Bachelors degree & 48 & 32.0 \\
\cline { 2 - 4 } & Masters degree & 28 & 18.7 \\
\cline { 2 - 4 } & Post Graduate degree & 55 & 36.7 \\
\hline
\end{tabular}

\subsection{Stability of the Measure:}

The stability of the measure was tested using Cronbach's alpha coefficient, it is shown from Table (2) that:

1. Alpha value related to items of trust dimension equals to 0.88 .

2. Alpha value related to items of Satisfaction dimension equals to 0.86 .

3. Alpha value related to items of management activities dimension equals to 0.93 .

4. Alpha value related to items of customer retention dimension equals to 0.94

5. Alpha value related to all items equals to 0.96 .

All these values are greater than 0.60 , which means that the measure is stable. 


\section{Macrothink}

Table 2. Alpha Chronbach values

\begin{tabular}{|l|c|}
\hline Dimension & Alpha \\
\hline Trust & 0.88 \\
\hline Satisfaction & 0.86 \\
\hline management activities & 0.93 \\
\hline Retention & 0.94 \\
\hline All items together & 0.96 \\
\hline
\end{tabular}

\subsubsection{Hypotheses:}

\subsubsection{First hypothesis}

H0: There is no impact of implementing customer relationship management to increase the customer trust in Umaid Bahwan.

Table 3 shows that all the items have a arithmetic means greater than 3.00 and p-value less than 0.05 which means that they are statistically significant. Item (5) which measure the how much the information gotten from the hotel is accurate, came in the first rank with an arithmetic average of 4.12 with a high degree. Item (3) which measure how muchUmaid Bhwan employees have good skills came in the second rank with an arithmetic average of 4.11 with a high degree too. Item (4) which measures the how much Umaid Bhwan employees are trusted came in the third rank with an arithmetic average of 4.05 with a high degree. The other items got medium degrees decently ordered according to the arithmetic mean: $8,2,1,6$, and 7 .

\subsubsection{Test of first hypothesis}

The table shows that all grouped items have a mean of 3.97, and 0.00 level of significance (p-value), which means that this hypothesis is rejected. Which means there is impact of implementing customer relationship management to increase the customer trust in UMAID BHWAN with a medium degree? 


\section{$\triangle$ Macrothink}

Asian Journal of Finance \& Accounting

ISSN 1946-052X

2012, Vol. 4, No. 1

Table 3. Arithmetic mean, Standard deviation, $t$ value and significance level (P-Value) in terms of trust

\begin{tabular}{|l|l|l|l|l|l|l|l|}
\hline $\begin{array}{l}\text { Item } \\
\text { No }\end{array}$ & Item details & $\begin{array}{l}\text { Arith } \\
\text { mean }\end{array}$ & $\begin{array}{l}\text { Std } \\
\text { dev }\end{array}$ & $\begin{array}{l}\text { T } \\
\text { Value }\end{array}$ & $\begin{array}{l}\text { P- } \\
\text { Value }\end{array}$ & Rank & Degree \\
\hline 1 & $\begin{array}{l}\text { Umaid Bhwan employees have } \\
\text { good skills }\end{array}$ & 3.92 & 0.70 & 16.29 & 0.00 & 6 & Moderate \\
\hline 2 & $\begin{array}{l}\text { You feel confident with dealing } \\
\text { with Umaid Bhwan }\end{array}$ & 3.93 & 0.53 & 21.33 & 0.00 & 5 & Moderate \\
\hline 3 & $\begin{array}{l}\text { Umaid Bhwan employees have } \\
\text { good skills }\end{array}$ & 4.11 & 0.55 & 24.79 & 0.00 & 2 & $\begin{array}{l}\text { high } \\
\text { degree }\end{array}$ \\
\hline 4 & $\begin{array}{l}\text { Umaid Bhwan employees are } \\
\text { trusted }\end{array}$ & 4.05 & 0.52 & 24.54 & 0.00 & 3 & $\begin{array}{l}\text { high } \\
\text { degree }\end{array}$ \\
\hline 5 & $\begin{array}{l}\text { The information you get from the } \\
\text { hotel is accurate }\end{array}$ & 4.12 & 0.64 & 21.30 & 0.00 & 1 & $\begin{array}{l}\text { high } \\
\text { degree }\end{array}$ \\
\hline 6 & $\begin{array}{l}\text { The hotel always exert good efforts } \\
\text { to fulfill its promises }\end{array}$ & 3.88 & 0.65 & 16.47 & 0.00 & 7 & \begin{tabular}{l} 
Moderate \\
\hline 7
\end{tabular} \\
$\begin{array}{l}\text { The hotel respects it promises as } \\
\text { expected }\end{array}$ & 3.81 & 0.61 & 16.43 & 0.00 & 8 & Moderate \\
\hline 8 & $\begin{array}{l}\text { You get the hotels services as } \\
\text { promised }\end{array}$ & 3.94 & 0.77 & 14.94 & 0.00 & 4 & Moderate \\
\hline & All grouped items & 3.97 & 0.47 & 25.41 & 0.00 & ----- & Moderate \\
\hline
\end{tabular}

\subsubsection{Second hypothesis}

There is no impact of implementing customer relationship management on customer satisfaction in Umaid Bahwan.

Table 4 shows that all the items have a arithmetic means greater than 3.00 and p-value less than 0.05 which means that they are statistically significant. Item (12) which measures the how much the hotel always provides customers with what he need, came in the first rank with an arithmetic average of 4.05 with a high degree. Item (11) which measure how much Umaid Bahwan hotel comply with its obligations towards customer, came in the second rank with an arithmetic average of 3.95 with a medium degree. Item (9) which measures the how much all of customer's transactions are highly protected came in the third rank with an arithmetic average of 3.94 with a medium degree. Items number 15, 13,14, 10, 17, 16 got medium degrees. Item number 18, which measures the how much customer is happy in dealing with Umaid Bahwan hotel, came in the last rank with an arithmetic average of 3.48 with a weak degree.

\subsubsection{Test of second hypothesis:}

The table shows that all grouped items has a mean of 3.78, and 0.00 level of significance (p-value), which means that this hypothesis is rejected. Which means there is there is impact of implementing customer relationship management on customer satisfaction in Umaid 
Bahwan with a medium degree?

Table 4. Arithmetic mean, Standard deviation, $\mathrm{t}$ value and significance level (P-Value) in terms of satisfaction.

\begin{tabular}{|c|c|c|c|c|c|c|c|}
\hline $\begin{array}{l}\text { Item } \\
\text { No }\end{array}$ & Item details & $\begin{array}{l}\text { Arith } \\
\text { mean }\end{array}$ & $\begin{array}{l}\text { Std } \\
\text { dev }\end{array}$ & $\begin{array}{l}\mathrm{T} \\
\text { Value }\end{array}$ & $\begin{array}{l}\text { P- } \\
\text { Value }\end{array}$ & Rank & Degree \\
\hline 9 & $\begin{array}{l}\text { All of yours transactions are } \\
\text { highly protected }\end{array}$ & 3.94 & 0.62 & 18.70 & 0.00 & 3 & Moderate \\
\hline 10 & $\begin{array}{l}\text { The hotel provides quality } \\
\text { service consistently }\end{array}$ & 3.76 & 0.54 & 17.26 & 0.00 & 7 & Moderate \\
\hline 11 & $\begin{array}{l}\text { Umaid Bahwan hotel comply } \\
\text { with its obligations towards } \\
\text { you }\end{array}$ & 3.95 & 0.69 & 16.95 & 0.00 & 2 & Moderate \\
\hline 12 & $\begin{array}{l}\text { The hotel always provides you } \\
\text { with what you need }\end{array}$ & 4.05 & 0.69 & 18.61 & 0.00 & 1 & $\begin{array}{l}\text { high } \\
\text { degree }\end{array}$ \\
\hline 13 & $\begin{array}{l}\text { Umaid Bahwan provides you } \\
\text { with needed information in } \\
\text { the specified time }\end{array}$ & 3.78 & 0.78 & 12.31 & 0.00 & 5 & Moderate \\
\hline 14 & $\begin{array}{l}\text { Umaid Bhwan employees pay } \\
\text { you special attention }\end{array}$ & 3.77 & 0.71 & 13.25 & 0.00 & 6 & Moderate \\
\hline 15 & $\begin{array}{l}\text { Umaid Bhwan employees are } \\
\text { willing to provide you with } \\
\text { any need }\end{array}$ & 3.81 & 0.86 & 11.53 & 0.00 & 4 & moderate \\
\hline 16 & $\begin{array}{l}\text { Umaid Bhwan responsibilities } \\
\text { towards the customers are } \\
\text { respected }\end{array}$ & 3.54 & 0.97 & 6.84 & 0.00 & 9 & Moderate \\
\hline 17 & $\begin{array}{l}\text { You will not switch to other } \\
\text { hotel }\end{array}$ & 3.69 & 0.57 & 14.98 & 0.00 & 8 & Moderate \\
\hline 18 & $\begin{array}{l}\text { You are happy in dealing with } \\
\text { Umaid Bahwan hotel }\end{array}$ & 3.48 & 0.68 & 8.61 & 0.00 & 10 & Weak \\
\hline & Total & 3.78 & 0.49 & 19.54 & 0.00 & & Moderate \\
\hline
\end{tabular}

\subsubsection{Third hypothesis:}

Umaid Bahwan hotel don't implement customer relationship management in its management activities.

Table 5 shows that all the items have an arithmetic means greater than 3.00 and p-value less than 0.05 , which means that they are statistically significant. Item (24) which measures the how much customer are informed with any new hostelling product, came in the first rank with an arithmetic average of 4.00 with a high degree. Item (28) which measure how much Umaid Bahwan always tries to build up very close relationship, came in the second rank with an arithmetic average of 3.99 with a medium degree. Item (25) which measures the how 
much Umaid Bhwan employees know how to serve customer, came in the third rank with an arithmetic average of 3.94 with a medium degree. The other items got medium degrees decently ordered according to the arithmetic mean: 21, 22, 27, 23, 26, 220, and 29.

\subsubsection{Test of third hypothesis}

The table shows that all grouped items has a mean of 3.70, and 0.00 level of significance (p-value), which means that this hypothesis is rejected. This means that Umaid Bahwan hotel implement customer relationship management in its management activities with a medium degree.

Table 5. Arithmetic mean, Standard deviation, t value and significance level (P-Value) in terms of management activities

\begin{tabular}{|c|c|c|c|c|c|c|c|}
\hline $\begin{array}{l}\text { Item } \\
\text { No }\end{array}$ & Item details & $\begin{array}{l}\text { Arith } \\
\text { mean }\end{array}$ & $\begin{array}{l}\text { Std } \\
\text { dev }\end{array}$ & $\begin{array}{l}\mathrm{T} \\
\text { Value }\end{array}$ & $\begin{array}{l}\text { P- } \\
\text { Value }\end{array}$ & rank & Degree \\
\hline 19 & $\begin{array}{l}\text { Umaid Bahwan services are } \\
\text { updated to meet customers need. } \\
\text { Actives of management }\end{array}$ & 3.70 & 0.89 & 9.65 & 0.00 & 11 & Moderate \\
\hline 20 & $\begin{array}{l}\text { There is a flexibility in hotels } \\
\text { services }\end{array}$ & 3.75 & 0.63 & 14.56 & 0.00 & 9 & Moderate \\
\hline 21 & $\begin{array}{l}\text { Umaid Bahwan hotel commit } \\
\text { itself to your personal needs }\end{array}$ & 3.92 & 0.54 & 20.97 & 0.00 & 4 & Moderate \\
\hline 22 & $\begin{array}{l}\text { Information provided by the hotel } \\
\text { are trustworthy }\end{array}$ & 3.91 & 0.43 & 25.86 & 0.00 & 5 & moderate \\
\hline 23 & $\begin{array}{l}\text { The hotel provides you with an } \\
\text { access to its services }\end{array}$ & 3.81 & 0.61 & 16.43 & 0.00 & 7 & Moderate \\
\hline 24 & $\begin{array}{l}\text { You are informed with any new } \\
\text { hotel product }\end{array}$ & 4.00 & 0.73 & 16.72 & 0.00 & 1 & $\begin{array}{c}\text { high } \\
\text { degree }\end{array}$ \\
\hline 25 & $\begin{array}{l}\text { Umaid Bhwan employees know } \\
\text { how to serve you }\end{array}$ & 3.94 & 0.70 & 16.51 & 0.00 & 3 & Moderate \\
\hline 26 & $\begin{array}{l}\text { Umaid Bhwan staff know how to } \\
\text { solve you problems }\end{array}$ & 3.77 & 0.78 & 12.17 & 0.00 & 8 & Moderate \\
\hline 27 & $\begin{array}{l}\text { Problems with the hotel are } \\
\text { solved quickly }\end{array}$ & 3.81 & 0.86 & 11.53 & 0.00 & 6 & Moderate \\
\hline 28 & $\begin{array}{l}\text { Umaid Bahwan always tries to } \\
\text { build up very close relationship }\end{array}$ & 3.99 & 0.58 & 20.87 & 0.00 & 2 & Moderate \\
\hline \multirow[t]{2}{*}{29} & $\begin{array}{l}\text { Umaid Bhwan service quality is } \\
\text { matching with your needs }\end{array}$ & 3.72 & 0.86 & 10.25 & 0.00 & 10 & Moderate \\
\hline & Total & 3.70 & 0.89 & 9.65 & 0.00 & ---- & Moderate \\
\hline
\end{tabular}

\subsubsection{Fourth hypothesis}

there are no relation between Customer Relationship Management and customer retention in Umaid Bahwan. 
Table 6 shows that all the items have an arithmetic means greater than 3.00 and p-value less than 0.05 , which means that they are statistically significant. Item (37) which measures the problem with the hotel, it can easily solved friendly - retention, came in the first rank with an arithmetic average of 4.01 with a high degree. Item (35) which measure how much hotel policy based on avoiding any potential problems - retention, came in the second rank with an arithmetic average of 3.99 with a medium degree. Item (34) which measures the how the Umaid Bhwan policy respect customer's own privacy - retention, came in the third rank with an arithmetic average of 3.98 with a medium degree. The other items got medium degrees decently ordered according to the arithmetic mean:39, 41, 36, 30, 32, 38, 40 33, and 31.

\subsubsection{Test of fourth hypothesis}

The table shows that all grouped items has a mean of 3.87, and 0.00 level of significance (p-value), which means that this hypothesis is rejected. Which means that there are relation between Customer Relationship Management and customer retention in Umaid Bahwan with a medium degree?

Table 6. Arithmetic mean, Standard deviation, t value and significance level (P-Value) in terms of customer retention

\begin{tabular}{|c|c|c|c|c|c|c|c|}
\hline $\begin{array}{l}\text { Item } \\
\text { No }\end{array}$ & Item details & $\begin{array}{l}\text { Arith. } \\
\text { mean }\end{array}$ & $\begin{array}{l}\text { Std } \\
\text { dev }\end{array}$ & $\begin{array}{l}\mathrm{T} \\
\text { value }\end{array}$ & $\begin{array}{l}\text { P- } \\
\text { Value }\end{array}$ & Rank & degree \\
\hline 30 & Hotel tries to keep up with new hotel services & 3.87 & 0.66 & 16.25 & 0.00 & 7 & moderate \\
\hline 31 & $\begin{array}{l}\text { The hotel keeps you updated with new services } \\
\text { available }\end{array}$ & 3.64 & 0.67 & 11.73 & 0.00 & 12 & moderate \\
\hline 32 & $\begin{array}{l}\text { There is a continuous contact from the hotel } \\
\text { side }\end{array}$ & 3.86 & 0.48 & 22.03 & 0.00 & 8 & moderate \\
\hline 33 & $\begin{array}{l}\text { Umaid Bhwan employees focus on your own } \\
\text { needs }\end{array}$ & 3.75 & 0.54 & 17.00 & 0.00 & 11 & moderate \\
\hline 34 & $\begin{array}{l}\text { The Umaid Bhwan policy respect your own } \\
\text { privacy }\end{array}$ & 3.98 & 0.67 & 18.16 & 0.00 & 3 & moderate \\
\hline 35 & $\begin{array}{l}\text { Your hotel policy based on avoiding any } \\
\text { potential problems }\end{array}$ & 3.99 & 0.58 & 20.87 & 0.00 & 2 & moderate \\
\hline 36 & $\begin{array}{l}\text { The hotel is able to negotiate the problems with } \\
\text { you }\end{array}$ & 3.88 & 0.65 & 16.47 & 0.00 & 6 & moderate \\
\hline 37 & $\begin{array}{l}\text { When you have a problem with the hotel, it can } \\
\text { easily solved friendly }\end{array}$ & 4.01 & 0.80 & 15.26 & 0.00 & 1 & $\begin{array}{l}\text { High } \\
\text { degree }\end{array}$ \\
\hline 38 & $\begin{array}{l}\text { In General Umaid Bhwan services are of high } \\
\text { quality }\end{array}$ & 3.83 & 0.83 & 12.27 & 0.00 & 9 & moderate \\
\hline 39 & $\begin{array}{l}\text { You feel respectful by Umaid Bhwan } \\
\text { employees }\end{array}$ & 3.95 & 0.69 & 16.73 & 0.00 & 4 & moderate \\
\hline 40 & You are satisfied in dealing with the hotel & 3.82 & 0.97 & 10.36 & 0.00 & 10 & moderate \\
\hline \multirow[t]{2}{*}{41} & You like to stay with your hotel & 3.88 & 0.73 & 14.72 & 0.00 & 5 & moderate \\
\hline & Total & 3.87 & 0.54 & 19.92 & 0.00 & & moderate \\
\hline
\end{tabular}




\section{Results}

1. There is impact of implementing customer relationship management to increase the customer trust in Umaid Bahwan with a medium degree, where UMAID BHWAN employees have good skills, customers feel confident with dealing with UMAID BHWAN hotel, Umaid Bhwan employees have good skills, Umaid Bhwan employees are trusted, the information customers get from the hotel is accurate, the hotel always exert good efforts to fulfill its promises, the hotel respects it promises as expected, and customers get the hotels services as promised.

2. There is impact of implementing customer relationship management on customer satisfaction in Umaid Bahwan with a medium degree, where all of customer's transactions are highly protected, the hotel provides quality service consistently, Umaid Bahwan hotel comply with its obligations towards customer, the hotel always provides customer with what he need, Umaid Bahwan provides customer with needed information in the specified time, Umaid Bhwan employees pay customer special attention, Umaid Bhwan employees are willing to provide customer with any need, Umaid Bhwan responsibilities towards the customers are respected, customer will not switch to other hotel, and customers are happy in dealing with Umaid Bahwan hotel.

3. Umaid Bahwan hotel implements customer relationship management in its management activities with a medium degree, where Umaid Bahwan services are updated to meet customers need. Actives of management,there is a flexibility in hotels services, Umaid Bahwan hotel commit itself to customer's personal needs, information provided by the hotel are trustworthy, the hotel provides customer with an access to its services, customers are informed with any new hotel product, Umaid Bhwan employees know how to serve customer, Umaid Bhwan staff know how to solve customer problems, problems with the hotel are solved quickly, Umaid Bahwan always tries to build up very close relationship, Umaid Bhwan service quality is matching with customer's needs.

4. There are relation between customer relationship management and customer retention in Umaid Bahwan with a medium degree, where the hotel keeps customer updated with new services available, there is a continuous contact from the hotel side, Umaid Bhwan employees focus on customer's own needs, the Umaid Bhwan policy respect customer's own privacy, the hotel policy based on avoiding any potential problems, the hotel is able to negotiate the problems with customer,when customer have a problem with the hotel, it can easily solved friendly, in General Umaid Bhwan services are of high quality, customer feel respectful by Umaid Bhwan employees, customers are satisfied in dealing with the hotel, and customer like to stay with their hotel. 
5. There are no differences in impact of customer relationship management on customers due to gender, age, income, occupation, education?

\section{Suggestions}

Based on the results of statistical analysis, which show the impact of Customer Relations Management on the level of client's satisfaction, confidence and the retaining of the clients of the State Hotel of India, it is clear that there is no company in the world dropped from defects and imperfect. Without doubt, every company should scrutinize and upgrade its plans despite of its success to identify the new strategies, which appropriate to the developed management surroundings, which specified the needs and desires of old, or new consumers.

The statistical analysis shows that the Customer Relationship Management has moderate influence on the level of client's satisfaction, confidence and the retaining of the clients of the State Hotel of India. To increase the efficiency of the State Hotel of India, we recommend the followings: -

1. The Umaid Bhwan manager should focus on the staff's scientific and practical skills and capabilities. To raise their positive psychological level, to live up to the best level of dealing with consumers in line with the concept of Customer Relationship Management, the Umaid Bhwan manager should provide them training and increase their motivation by rewards.

2. The company must continue in management studies in order to identify the consumers' present and future needs and desires to meet their desires and needs as well as they expected. This will be achieved by qualified and trained staff cope with the development of current and future surroundings to win the consumer's satisfaction.

3. The institution should deal consumers trustworthily and credibly through commitment to the delivery dates of orders without bias to gain consumer's trust of the hotel institution.

4. The institution must take care of the staff's external appearance in order to win the consumer's satisfaction.

5. The institution must allocate places for waiting provided with hospitality services so that the consumer does not feel bored during the waiting period this service increases consumer's happiness and satisfaction.

6. The directors of the Hotel should improve the image of the Hotel with regard to the consumer's point of view by good technique and speed in completing the work which increases consumer's happiness and satisfaction

7. The hotel institution must increase the interest in the periodical awards to consumers, which increases the level of satisfaction and loyalty to the organization. 
8. The hotel institution must increase its attention and focus on consumer complaints and suggestions, which increase the level of satisfaction and loyalty to the organization and keep the consumer for the longest possible period.

9. The hotel institution should classify offering services regarding to the consumer groups in line with their culture and demographic factors, which increase the consumer's satisfaction.

10. Consumers must be noticed that they have guarantees on their deposits. These guarantees should be activated to increase consumer's confidence in the organization.

\section{References}

Chen, I. J., \& Popvich, K. (2003). Understanding customer relationship management (CRM): People, process, and technology. Business Process Management Journal, 9, 672-688. http://dx.doi.org/10.1108/14637150310496758

Colgate, M., Buchanan-Oliver, M., \& Elmsly, R. (2006). Relationship benefits in an internet environment, Managing Service Quality, Vol. 15 No. 5, pp. 426-436. http://dx.doi.org/10.1108/09604520510617284

Germany. California Management Review, Vol. 37 No. 4, pp. 45-72.

Henning-Thurau, T., Gwinner, K.P., \& Gremler, D.D. (2002). Understanding relationship management outcomes: an integration of relational benefits and relationship quality. Journal of Service Research, Vol. 4 No. 3, pp. 230-247. http://dx.doi.org/10.1177/1094670502004003006

Jackson, D. J. (1994). Relationship selling: The personalization of relationship management. Asia-Australia Management Journal, $\quad$ 2, http://dx.doi.org/10.1016/S1320-1646(94)70277-X

Johnson, J.L. (1999). Relationship quality in business-to-business service context. Journal of Management, Vol. 24 No. 3, pp. 45-67.

Keltner, B. (1995). Relationship hotel and competitive advantage: evidence from the US and

Kotler, P. (1992,April,2). It’s time for total management. Business Week,( 2968) 31-33.

Light, B. (2003). CRM packaged software: A study of organizational experiences. Business Process Management Journal, 9, 303-316. http://dx.doi.org/10.1108/14637150310496712

Ndubisi, N.O. (2003). Service quality: understanding customer perception and reaction, and its impact on business. International Journal of Business, Vol. 5 No. 2, pp. 190-207.

O’Malley, L., \& Tynan, C. (2000). Relationship management in consumer markets. Rhetoric or reality?, European Journal of Management, Vol. 34 No. 7, pp. 797-815. 